\title{
Green Supplier selection for plastic industry using integrated model based on Pythagorean fuzzy AHP and fuzzy TOPSIS
}

\author{
Melih YÜCESAN ID a \\ a Faculty of Engineering, Department of Mechanical Engineering, Munzur University, Tunceli, Turkey. \\ melihyucesan@munzur.edu.tr
}

\begin{tabular}{|c|c|}
\hline ARTICLE INFO & ABSTRACT \\
\hline $\begin{array}{l}\text { Keywords: } \\
\text { Green supplier selection } \\
\text { Fuzzy set theory } \\
\text { FTOPSIS }\end{array}$ & $\begin{array}{l}\text { Purpose -Supply Chain Management (SCM) has emerged in recent years and is now increasing } \\
\text { in popularity. It aims to reduce production costs, maximize earnings, improve customer } \\
\text { relations, improve inventory management and increase customer satisfaction. Reducing total } \\
\text { cost of procurement is one of the most important parameters in aligning the objectives of } \\
\text { partners in a supply network. }\end{array}$ \\
\hline $\begin{array}{l}\text { Received } 15 \text { September } 2018 \\
\text { Revised } 19 \text { January } 2019 \\
\text { Accepted } 10 \text { February } 2019\end{array}$ & $\begin{array}{l}\text { Design/methodology/approach - This paper proposed Pythagorean Fuzzy Analytic Hierarchy } \\
\text { Process (PFAHP) and Fuzzy Technique for Order Preference by Similarity to Ideal Solution } \\
\text { (FTOPSIS) integrated model for green supplier selection for plastic industry. In the first phase of } \\
\text { the study, the parameters to be used in selecting suppliers are determined. Then, by making } \\
\text { pairwise comparisons, the weights of these parameters are determined with PFAHP method. } \\
\text { Finally, the supplier that is most suitable for } 3 \text { suppliers is determined using the FTOPSIS } \\
\text { method. }\end{array}$ \\
\hline \multirow[t]{2}{*}{$\begin{array}{l}\text { Article Classification: } \\
\text { Research Article }\end{array}$} & $\begin{array}{l}\text { Findings - Among the criteria evaluated by } 5 \text { experts, the most important criteria, the } \\
\text { parameters of the Inspection methods and management and organizations are determined as } \\
\text { the most important parameters respectively. The supplier no. } 3 \text { has been identified as the most } \\
\text { suitable supplier. }\end{array}$ \\
\hline & $\begin{array}{l}\text { Discussion -The case study is performed under a fuzzy environment to reduce uncertainty and } \\
\text { vagueness, and linguistic variables parameterized by interval-valued Pythagorean and } \\
\text { triangular fuzzy numbers are used. Through the case study, } 8 \text { main and } 45 \text { sub-criteria supplier } \\
\text { selection evaluation criteria used to assess } 3 \text { suppliers by FTOPSIS. However, our study has } \\
\text { some disadvantages and possible further work is recommended. Other possible different fuzzy } \\
\text { sets can be used in the projected method. }\end{array}$ \\
\hline
\end{tabular}

\section{Introduction}

Supply Chain Management (SCM) has emerged in recent years and is now increasing in popularity. Academic and industrial fields are interested in SCM. SCM's primary goal is to reduce supply chain (SC) risk. It is also a goal of the SCM to reduce production costs, maximize earnings, improve customer relations, improve inventory management and increase customer satisfaction (Chou and Chang, 2008; Ha and Krishnan, 2008). Supplier selection decisions can be made at different phases of the life sequence of a product, in the case of multiple suppliers. (Bai and Sarkis, 2010). Effective supplier selection plays a vital role in the success of businesses, especially in today's competitive environment. Careful consideration of suppliers by decision makers is one of the most challenging stages of the decision-making process, as there are a number of conflicting goals to consider (Liu and Hai, 2005). Manufacturing industries should work with different suppliers to ensure that their activities continue in a healthy manner (Ghodsypour and O’Brien, 1998).

Reducing total cost of procurement is one of the most important parameters in aligning the objectives of partners in a supply network. Nowadays the social and environmental effects of business activities and employees' health have become as important as the profits of business owners. The environmental and social 
impacts of commercial activities have become publicly monitored. The integration of ecological, economic and social concerns into business decisions that promote sustainable development has become a major strategic activity for many global industries (Moheb-Alizadeh and Handfield, 2017; Lee, 2009). Sustainable SCM deals with the coordination of companies throughout the supplier chain, as well as the management of materials, meeting the needs of customers and stakeholders (Seuring, and Müller 2008).

Many supplier selection approach in the literature are concerned with the benefits that can be gained from the selection of supplier (Lee, 2009). In fact, the cost and risks involved in choosing suppliers should be addressed more extensively. There are many studies that include conventional criteria, but green suppliers and environmental criteria are very limited in the literature. For this reason, the primary objective of this approach is to offer a green supplier model selection including environmental and economic criteria.

Many of the problems based on human evaluation are uncertain and it is hard to decide to determine exact numerical values. For this reason, evaluations of the suppliers based on the determined criteria are usually expressed linguistically by the decision-makers. Furthermore, it is also recognized that human judgment is always subjective and thus imprecise. The use of fuzzy logic is thought to give more favorable results in solving problems where decision makers have uncertain linguistic expressions.

This study aims to determine the most suitable supplier for plastic injection production in case there are conflicting objectives. Environmental criteria for materials in plastics production should be evaluated together with other criteria such as quality and cost. In addition, environmental criteria such as employee rights and work safety must be included in the decision-making model. The selection process should be adopted as a multi-criteria approach since some criteria in the supplier selection conflict with each other. In this study, 8 main and 45 sub-criteria were identified which play an important role in supplier selection. Experts in the field were compared these criteria using linguistic expressions. PFAHP was used to determine the criterion weights. Pythagorean fuzzy sets are an expansion of intuitionistic fuzzy sets. Pythagoras fuzzy sets are allowed the decision makers to express opinion about uncertainty and ideas about real-world problems more freely in MCDM problems. Potential 3 suppliers were rated linguistically by the FTOPSIS method. In the FTOPSIS method, the weights obtained by the PFAHP method were used.

\section{Literature Review}

\subsection{Supplier selection}

There are many studies in the literature related to supplier selection and evaluation. This current literature shows how the firm selection process affects firm operations. Some studies that do not include the Green and Environmental assessment parameters can be listed as follows.

Akarte et al. (2001) developed a web AHP origin decision making model for the supplier selection of casting enterprises. In this model, 18 criteria were determined. Suppliers were required to record and enter the raw specifications. To evaluate the suppliers, decision makers had to determine the relative importance weights Muralidharan et al. (2002) have identified 9 evaluation criteria. Using these criteria, they proposed a 5-step AHP-based model. During the linguistic evaluation of the criteria, the purchasing, warehouse and quality control experts of the business were assigned. Chan (2003) proposed the AHP model to help decision makers in supplier selection. The AHP method was used using 6 main criteria and 20 sub-criteria criteria. These evaluations were based on customer requirements. A different supplier choosing system for selecting suppliers which has its roots on AHP is proposed by Hou and Su (2007). Internal and external influences are considered when criteria are set. It was targeted to meet the needs of the market. Kahraman et al. (2003) and Chan and Kumar (2007) have proposed fuzzy AHP (FAHP) model for supplier selection for white goods manufacturers. The decision makers evaluated the criteria using linguistic expressions. Jain et al. (2018) proposed a decision support system using a combination of FAHP and TOPSIS methods for use in the Indian automotive industry. The weights of the parameters were computed by the FAHP method. Suppliers were rated by the TOPSIS method. Then the consistency of the results was tested. Awasthi et. get. (2018) proposed a sustainable supplier system using a combination of FAHP and Viekriterijumsko kompromisno rangiranje (VIKOR) methods. The study was designed as two parts. In the first part, FAHP was used to determine the weights. In the second part, the best suppliers are determined by the weights obtained and 
VIKOR method. Kumar and Dash (2018) uses fuzzy Delphi and AHP-DEMATEL methods to optimize the decision support systems of automobile manufacturing factories.

Supply chain management, which takes environmental and green criteria into consideration, has become important in recent years. Some work has been listed in this area. Recently, many methods for green supplier selection have been developed.

\subsection{Green supplier selection}

Noci (1997) designed green supplier evaluation system with using 4 green and environmental criteria using AHP. Enarsson (1998) proposed a quality improvement approach that takes environmental criteria into consideration using the Ishikawa fishbone diagram Walton, et al. (1998) suggested using a flow chart to determine proper methods and criteria for green supplier evaluation and selection. Handfield et.al. (2002) proposed a supplier assessment system using the AHP method, considering the green and environmental criteria. Lee et al. (2009) proposed a decision support system using the AHP method which considers the environmental problem and green supplier criteria in order to be used in the high-tech sector. Tsai and Huang (2009) used goal programming to optimize costs and value chain structure and proposed a procurement management model with green criteria. Zhu et al. (2010) has proposed a portfolio-based analytical method to improve the performance of green supplier management. Bai and Sarkis (2010) proposed a green supplier selection model using a rough set. Kuo et. al. (2010) proposed a model of green supplier selection using artificial neural networks and MADA methods. Zhu and Geng (2001) examined supply selection models using green and environmental criteria in large and medium-sized public enterprises in China. Handfield et al. (2002) used the AHP method to assess the relative importance of various environmental criteria. Hsu and $\mathrm{Hu}$ (2009) used the Analytic Network Process (ANP) method to select green suppliers. Suggesting that ANP could give more realistic results when choosing suppliers. Zouggari and Benyoucef (2012) offer a new model for group multi-criteria supplier selection problems using FAHP and FTOPSIS methods together. The proposed model can be easily modified by decision makers when needed. Kannan et al. (2013) used the integrated approach of FAHP, FTOPSIS and fuzzy linear programming in green supplier selection problems. They suggested that the proposed model evaluates suppliers according to qualitative and quantitative criteria. Denizhan et. al. (2017) compared green supplier selection and classic supplier selection methodologies. Supplier selection activities of the companies in eastern Turkey are evaluated. Green supplier selection criteria are determined using Fuzzy AHP method. It has been suggested that the results obtained with the green criterion and the choice of classic supplier are different. Çalık (2018) proposed type-2 FAHP and fuzzy linear programming combined model for asses to appropriate green supplier. Tayali (2017) aims to determine green supplier by weighted aggregated sum product Assessment method (WASPAS) to support the decision-making process of the enterprises by considering the interaction between supplier alternatives and the criteria affecting supplier selection.

The green supply chain did not provide consensus on all researchers (Ahi and Searcy, 2013). However, many researchers agree that businesses should be greener (Marcus and Fremeth, 2009). The green supply chain can be specify as the coordination of activities such as material management, information sharing, capital flow and cooperation, with the aim of minimizing the environmental impact of its operations by considering the financial interests of the company (Seuring and Müller, 2008).

Supplier selection is one of the most impactful elements that ensures that supply chain is sustainable and that the other operations of the enterprise are maintained (Kumar et al., 2014). A sustainable supply chain should include green and environmental criteria as well as economic targets (Ageron et al., 2012). In addition, the success of the sustainability-focused supply chain depends directly on the selection and selection of appropriate suppliers (Hsu et al., 2013). In general, decision makers take into consideration criteria such as quality, flexibility and price. But, when included in the green and environmental criteria, the supplier determination process becomes more complex. However, these criteria must be taken into consideration in recent years (Brandenburg et al., 2014, Azadi et al. 2015) The primary objective of the green supplier selection is to minimize pollution and other environmental effect and to recognize suppliers' environmental concerns and to help suppliers to resolve these problems to encourage improvements (Tseng, 2011; Lu et al., 2007). 


\section{Methodology}

\subsection{Pythagorean fuzzy sets}

Intuitionistic fuzzy sets are developed by Atanasov (1986). It has been used to express ambiguity in many real applications. These sets can be expressed in terms of membership functions, non-membership function and hesitancy degree. However, if the degree of membership and non-membership is greater than 1, Intuitionistic fuzzy set fails to express uncertainty. To overcome this weakness Yager (2014) proposed Pythagorean fuzzy sets. This set is an improved version of the intuitionistic fuzzy set. In many cases it expresses the uncertainty of real world problems more clearly (Oz et. al., 2018; Ilbahar et al., 2018; Gul, 2018; Ak and Gul, 2018; Yucesan and Kahraman, 2019).

Differently from the intuitionistic fuzzy sets, the entirety of membership and non-membership degrees may exceed 1 but the totality of squares cannot in Pythagorean fuzzy sets, (Ilbahar et al. 2018; Zeng et al. 2015; Zhang and $\mathrm{Xu}, 2014 ;$ Mete, 2018). This event is shown below in Definition (1).

Definition 1:. A Pythagorean fuzzy set $\mathrm{P}$ is an object having the procedure (Zhang and $\mathrm{Xu}, 2014)$ :

$$
P=\left\{<x, P\left(\mu_{P}(x), v_{P}(x)\right)>\mid x \in X\right\}
$$

where $\mu_{P}(x): X \mapsto[0,1]$ shows the degree of membership and $v_{P}(x): X \mapsto[0,1]$ shows the degree of nonmembership of the element $x \in X$ to $\mathrm{P}$, respectively, and, for every $x \in X$, it holds:

$0 \leq \mu_{P}(x)^{2}+v_{P}(x)^{2} \leq 1$

Definition 2: Let $\beta_{1}=P\left(\mu_{\beta_{1}}, v_{\beta_{1}}\right)$ and $\beta_{2}=P\left(\mu_{\beta_{2}}, v_{\beta_{2}}\right)$ be two Pythagorean fuzzy numbers, and $\lambda>0$, then the operations on these two Pythagorean fuzzy numbers are defined as follows (Zeng et al. 2015; Zhang and $\mathrm{Xu}, 2014)$ :

$$
\begin{aligned}
& \beta_{1} \oplus \beta_{2}=P\left(\sqrt{\mu_{\beta_{1}}{ }^{2}+\mu_{\beta_{2}}{ }^{2}-\mu_{\beta_{1}}{ }^{2} \mu_{\beta_{2}}{ }^{2}}, v_{\beta_{1}} v_{\beta_{2}}\right) \\
& \beta_{1} \otimes \beta_{2}=P\left(\mu_{\beta_{1}} \mu_{\beta_{2}}, \sqrt{v_{\beta_{1}}{ }^{2}+v_{\beta_{2}}{ }^{2}-v_{\beta_{1}}{ }^{2}{v_{\beta_{2}}}^{2}}\right) \\
& \lambda \beta_{1}=P\left(\sqrt{1-\left(1-\mu_{\beta_{1}}{ }^{2}\right.},{\left(v_{\beta_{1}}\right.}^{\lambda}\right), \lambda>0 \\
& \left.\beta_{1}^{\lambda}=P\left(\left(\mu_{\beta_{1}}\right)^{\lambda}, \sqrt{1-\left(1-v_{\beta_{1}}{ }^{2}\right.}\right)^{\lambda}\right), \lambda>0
\end{aligned}
$$

\subsection{PFAHP and related linguistic terms}

AHP method is extensively used multi-criteria decision-making problems (Perçin and Ayan, 2015). PFAHP is extension of AHP designed to express the real case issues more properly. This method is explained in following stages.

Step 1: The formula of compromised pairwise comparison matrix $A=\left(a_{i k}\right)_{m x m}$ depends on linguistic assessment of experts using a ruler projected by (Ilbahar et al. 2018) in Table 1. 
Table 1 Weighting scale for PAHP (Ilbahar et al. 2018)

\begin{tabular}{lcccc}
\hline \multirow{2}{*}{ Linguistic term } & \multicolumn{4}{c}{ Pythagorean fuzzy numbers } \\
\cline { 2 - 5 } & $\mu \mathrm{L}$ & $\mu \mathrm{U}$ & $\mathrm{VL}$ & $\mathrm{VU}$ \\
\hline Certainly low important (CLI) & 0.00 & 0.00 & 0.90 & 1.00 \\
Very low important (VLI) & 0.10 & 0.20 & 0.80 & 0.90 \\
Low important (LI) & 0.20 & 0.35 & 0.65 & 0.80 \\
Below average important (BAI) & 0.35 & 0.45 & 0.55 & 0.65 \\
Average important (AI) & 0.45 & 0.55 & 0.45 & 0.55 \\
Above average important (AAI) & 0.55 & 0.65 & 0.35 & 0.45 \\
High important (HI) & 0.65 & 0.80 & 0.20 & 0.35 \\
Very high important (VHI) & 0.80 & 0.90 & 0.10 & 0.20 \\
Certainly high important (CHI) & 0.90 & 1.00 & 0.00 & 0.00 \\
Exactly equal (EE) & 0.1965 & 0.1965 & 0.1965 & 0.1965 \\
\hline
\end{tabular}

Step 2: The difference matrices $D=\left(d_{i k}\right)_{m x m}$ are calculated using Eqs. (7) and (8):

$$
\begin{aligned}
& d_{i k_{L}}=\mu_{i k_{L}}^{2}-v_{i k_{U}}^{2} \\
& d_{i k_{U}}=\mu_{i k_{U}}^{2}-v_{i k_{L}}^{2}
\end{aligned}
$$

Step 3: Interval multiplicative matrix $S=\left(s_{i k}\right)_{m x m}$ is computed using Eqs. (9) and (10):

$S_{i k_{L}}=\sqrt{1000^{d_{L}}}$

$s_{i k_{U}}=\sqrt{1000^{d_{U}}}$

Step 4: The determinacy value $\tau=\left(\tau_{i k}\right)_{m x m}$ is calculated using Eq. (11):

$\tau_{i k}=1-\left(\mu_{i k_{U}}^{2}-\mu_{i k_{L}}^{2}\right)-\left(v_{i k_{U}}^{2}-v_{i k_{L}}^{2}\right)$

Step 5: The determinacy degrees are multiplied with $S=\left(s_{i k}\right)_{m x m}$ matrix for obtaining the matrix of weights, $T=\left(t_{i k}\right)_{m x m}$ before normalization using Eq. (12).

$t_{i k}=\left(\frac{s_{i k_{L}}+s_{i k_{U}}}{2}\right) \tau_{i k}$

Step 6: The normalized priority weights $w_{i}$ is computed via using Eq. (13).

$$
w_{i}=\frac{\sum_{k=1}^{m} t_{i k}}{\sum_{i=1}^{m} \sum_{k=1}^{m} t_{i k}}
$$

\subsection{Fuzzy TOPSIS}

Hwang and Yoon (1981) offers TOPSIS in order to find out the best alternative respect to the compromise solution concept. The compromise solution concept is way to select the smallest and the farthest distance from a negative ideal solution. Since the ratings while evaluating alternatives against criteria usually refer to the subjective uncertainty, TOPSIS is extended to consider the situation of fuzzy numbers (Tzeng and Huang, 2011; Celik et al. 2012). It was followed by the procedure of the Chen's (2000) FTOPSIS method in the case study of this work for the hazard prioritization aim. The steps are as in the following (Tzeng and Huang, 2011; Gul and Guneri, 2018; Carpitella et al. 2018):

Step 1: Alternative scores according to each parameter. The evaluation by the $\mathrm{K}$ number of experts and the

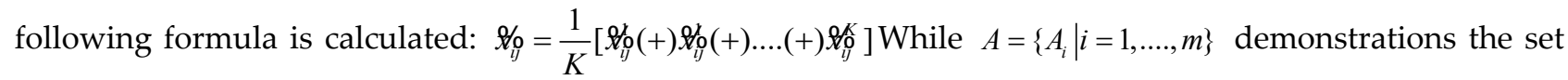
of alternatives, $C=\left\{C_{j} \mid j=1, \ldots, n\right\}$ represent the criteria set. Where $X=\left\{X_{i j} \mid i=1, \ldots, m ; j=1, \ldots ., n\right\}$ denotes the set of fuzzy ratings and $\mathscr{W}_{0}=\left\{\Re_{0} \mid j=1, \ldots, n\right\}$ is the set of fuzzy weights. The linguistic variables are described 
by trapezoidal fuzzy number as follows: $\ell_{i j}^{\prime}=\left(a_{i j}, b_{i j}, c_{i j}, d_{i j}\right)$. Tables 2 shows the linguistic terms (Samantra et al. 2017).

Table 2 Five-point fuzzy linguistic scale

\begin{tabular}{ll}
\hline Linguistic term & $\begin{array}{l}\text { Corresponding fuzzy } \\
\text { number }\end{array}$ \\
\hline Very high $(\mathrm{VH})$ & $(0.7,0.8,0.9,1)$ \\
High (H) & $(0.5,0.6,0.7,0.8)$ \\
Moderate (M) & $(0.3,0.4,0.5,0.6)$ \\
Low (L) & $(0.1,0.2,0.3,0.4)$ \\
Very low (VL) & $(0,0.1,0.2,0.3)$ \\
\hline
\end{tabular}

Step 2: Normalized ratings are computed by Eq. (6).

$\mathbb{R} / j=\left\{\begin{array}{l}\left(\frac{a_{i j}}{d_{j}^{*}}, \frac{b_{i j}}{d_{j}^{*}}, \frac{c_{i j}}{d_{j}^{*}}, \frac{d_{i j}}{d_{j}^{*}}\right), \text { where } d_{j}^{*}=\max _{i} d_{i j} \text { if } j \in \text { benefit criteria } \\ \left(\frac{a_{j}^{-}}{d_{i j}}, \frac{a_{j}^{-}}{c_{i j}}, \frac{a_{j}^{-}}{b_{i j}}, \frac{a_{j}^{-}}{a_{i j}}\right), \text { where } a_{j}^{-}=\min _{i} a_{i j} \text { if } j \in \cos \mathrm{t} \text { criteria }\end{array}\right.$

Step 3: Weighted normalized ratings are obtained by Eq. (7).

$$
\mathbb{P}_{i j}=w_{j}(x) \stackrel{\mathscr{R}}{i j},_{,} \quad i=1, \ldots, m ; j=1, \ldots ., n
$$

Step 4: The fuzzy positive ideal point (FPIS, $A^{*}$ ) and the negative ideal point (FNIS, A-) are calculated with Eqs. (8-9). $\mathrm{J}_{1}$ and $\mathrm{J}_{2}$ are represent the benefit and the cost attributes, respectively.

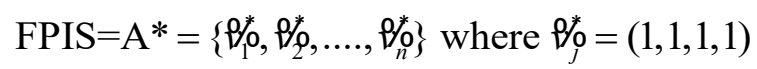

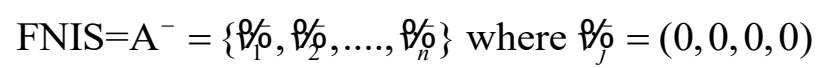

Step 5: In this stage it involves finding the difference between FPIS and FNIS. Eqs (10-11) is used for this calculation.

$$
\begin{aligned}
& \mathrm{S}_{\mathrm{i}}^{\mathrm{o}}=\sqrt{\frac{1}{4} \sum_{\mathrm{j}=1}^{\mathrm{n}}\left[\mathrm{Q}_{\mathrm{p}}-\mathrm{Q}_{\rho}^{\mathrm{j}}\right]^{2}}, \quad i=1, \ldots, \mathrm{m} \\
& \xi_{i}^{o}=\sqrt{\left.\frac{1}{4} \sum_{j=1}^{n}\left[Q_{p}-Q_{\rho}\right]^{2}\right]^{2}}, \quad i=1, \ldots ., m
\end{aligned}
$$

Step 6: Then, the similarities to the ideal solution are calculated with Eq.(12).

$$
C_{i}^{*}=\xi_{j}^{o} /\left(S_{j}^{o}+\xi_{j}^{o}\right), \quad i=1, \ldots, m
$$

\section{Case study}

Injection molding is one of the most common methods used in the production of plastic parts. Thanks to this method; complex, non-symmetric products can be produced. The injection method consists of 4 main stages. The production steps with plastic injection are shown in Figure 2. These stages are drying, blending and dosing, injection molding and regrinding, respectively (Madan et al.,2015; Yucesan et al., 2018).

In this respect, the quality of plastic injection production is directly related to the raw material selected. Therefore, to be successful in this sector, a good and sustainable supplier selection system is needed. 


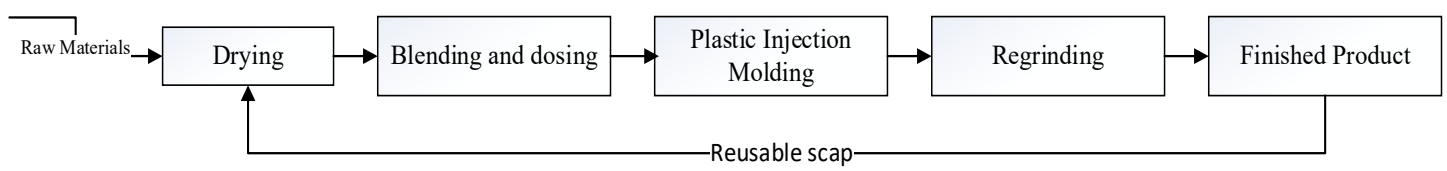

Figure 2. Stages of an injection molding facility

\subsection{Steps of the proposed approach}

The proposed model consists of 6 steps as shown in Figure 3. In the first phase of the study, the parameters to be used in selecting suppliers are determined. Then, by making pairwise comparisons, the weights of these parameters are determined with PFAHP method. After obtaining weights of the criteria, decision matrix will be completed. Finally, suppliers are evaluated by using FTOPSIS method.

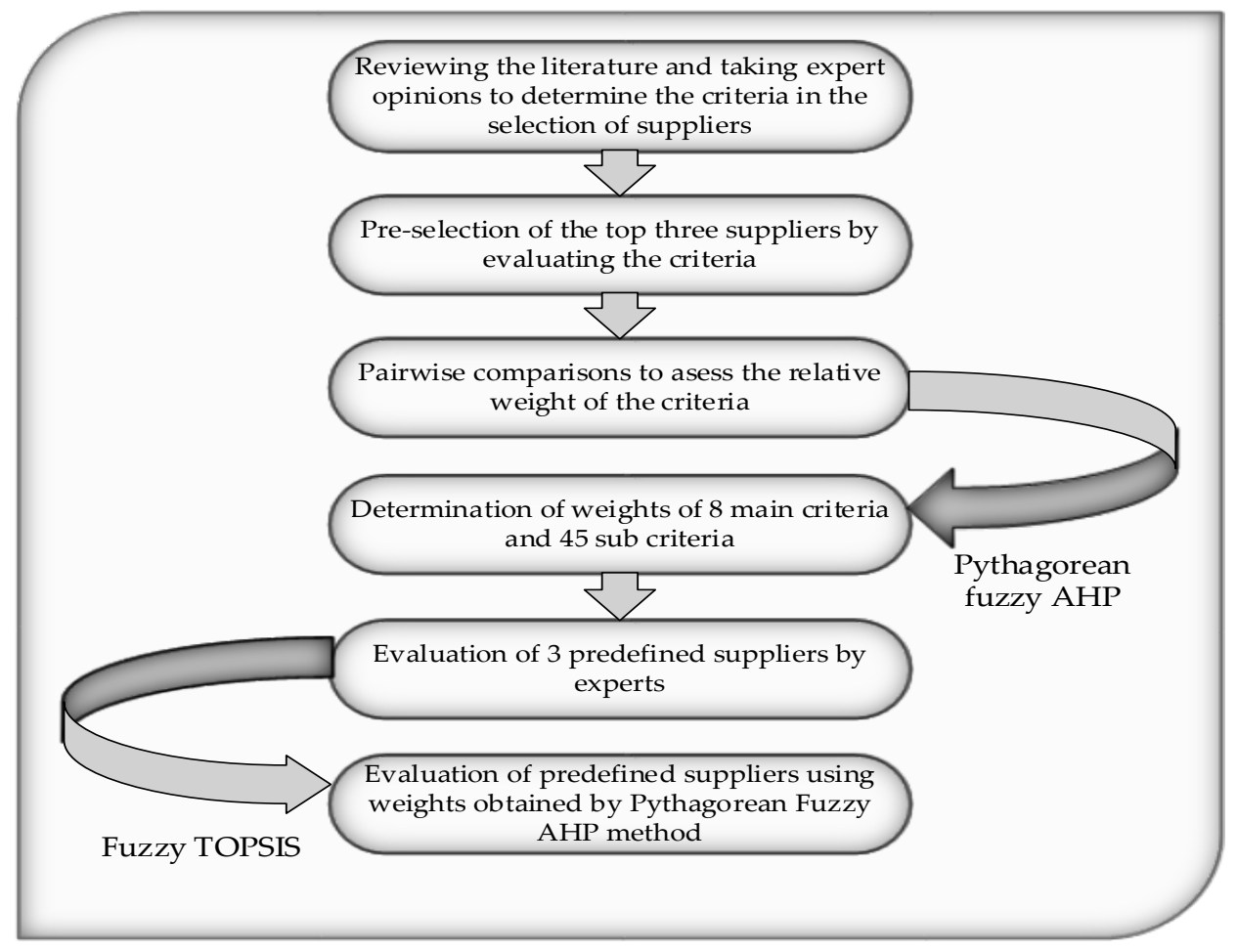

Figure 3. Green supplier selection stages

\subsection{Linguistic scales and their corresponding fuzzy numbers}

In this study, we benefited from two linguistic scales. First, we use the scale proposed by Ilbahar et al. (2018) in evaluating suppliers according to the main and the sub-criteria using pairwise comparison of PFAHP. That scale is based on Pythagorean fuzzy numbers (Table 1). Second, in evaluating suppliers with respect to the criteria using FTOPSIS, we apply the scale of Samantra et al. (2017). The prioritization of suppliers is performed by using five members' trapezoidal fuzzy linguistic scale (Table 2).

\subsection{Weighting calculation using PFAHP}

Eight main evaluation criteria including 45 sub-criteria are considered in this study to evaluate suppliers (Yucesan et al.,2018). Weighs for these 45 sub-criteria are obtained via FPAHP computations of 5 evaluators. 5 evaluators realized pairwise comparisons about the importance of weights of each evaluation criterion by using the linguistic expression defined in Table 1. At this stage, the linguistic expressions of the experts are transformed into fuzzy numbers. Since the evaluations of each expert were different, the averages of these evaluations are used. The aggregated compromised pairwise comparison matrix for the main criteria is presented in Table 4. The difference matrix $\mathrm{D}$ and interval multiplicative matrix $\mathrm{S}$ are also shown in Tables 56 ,

respectively. 
M. Yücesan 11/1 (2019) 26-41

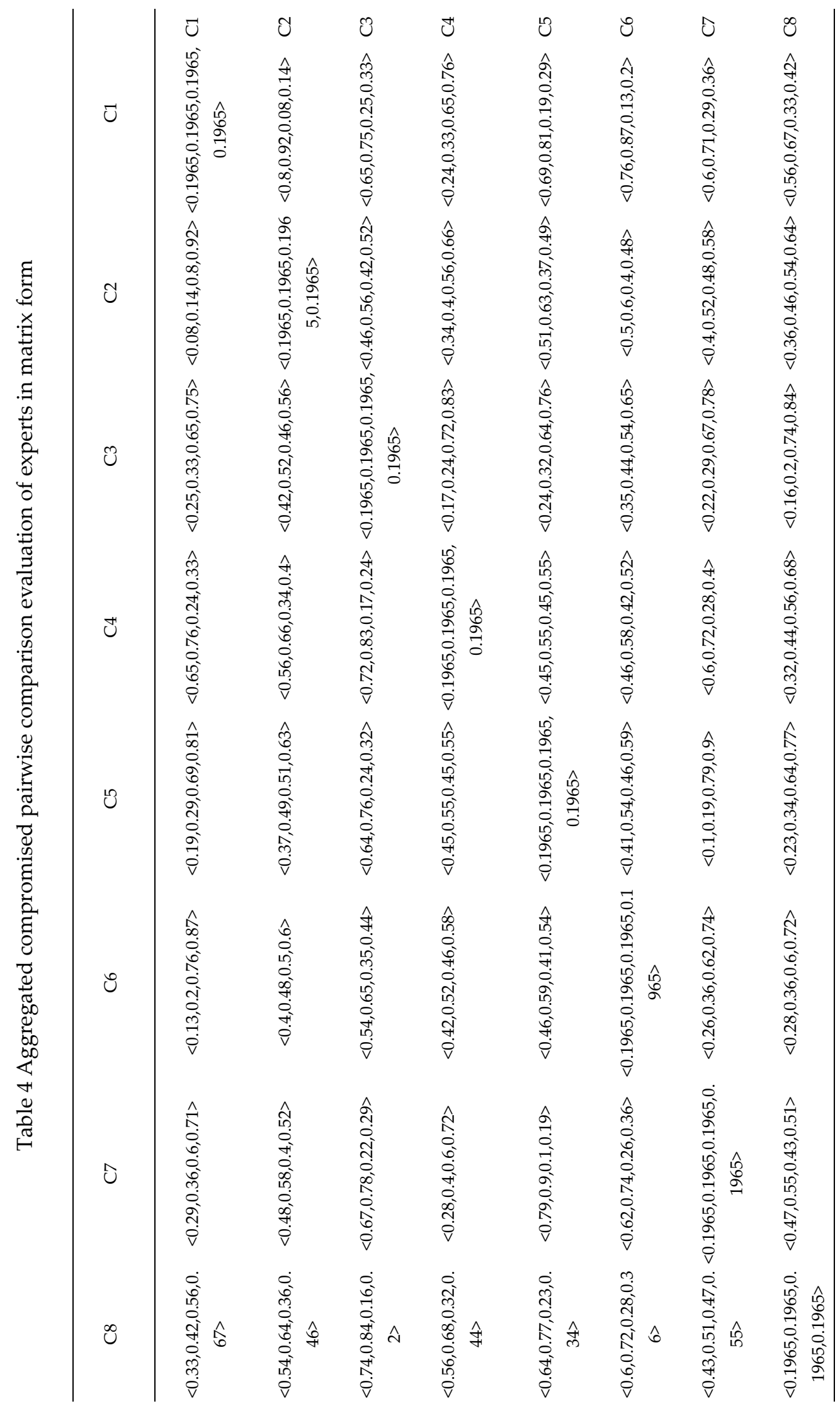


M. Yücesan 11/1 (2019) 26-41
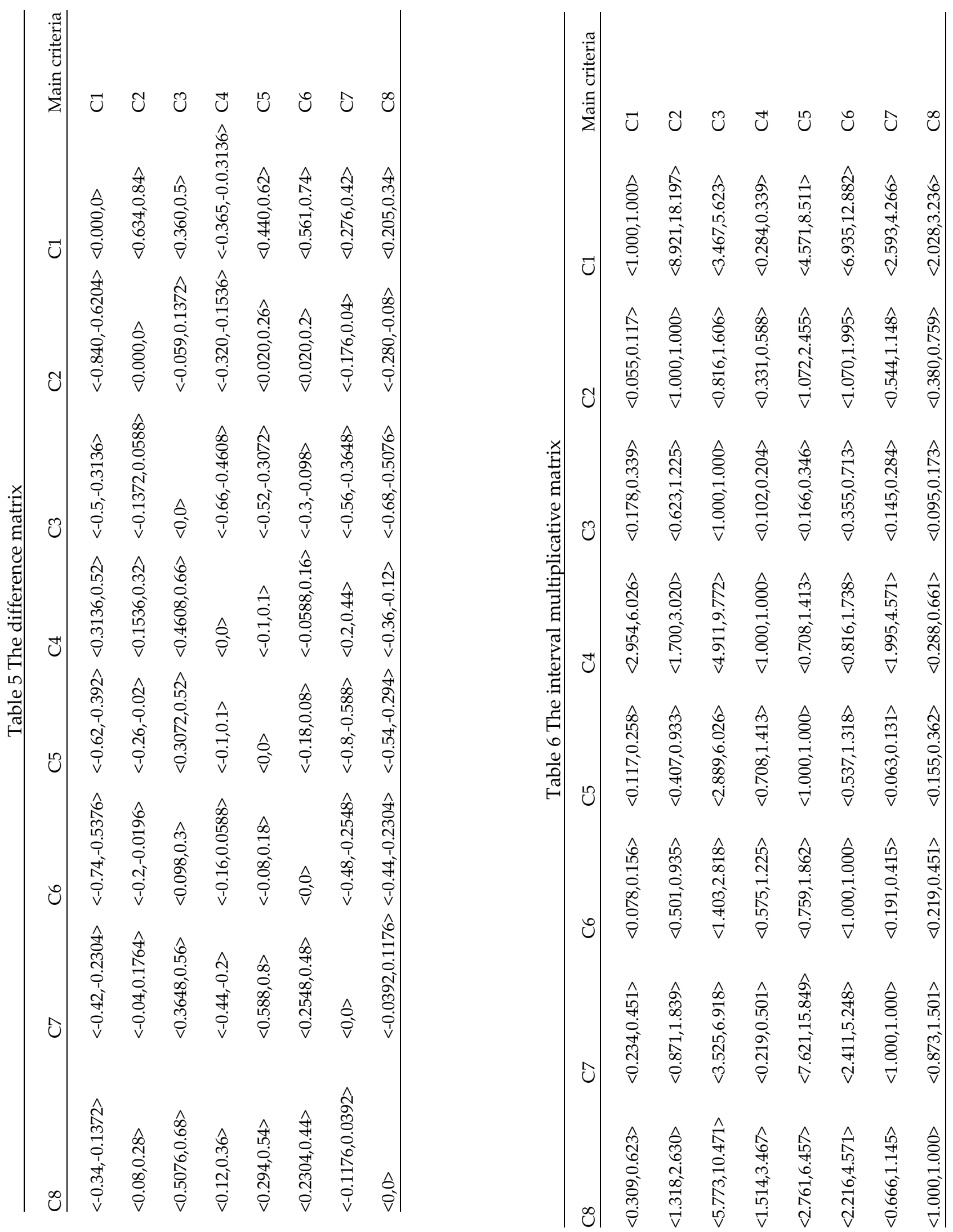
The determinacy value matrix is computed with Eq.(11) and matrix of weights before normalization as in Eq. (12) are represented in Tables 7-8, respectively.

Table 7 The determinacy value matrix $(\mathrm{T})$

\begin{tabular}{lllllllll}
\hline $\mathrm{T}$ & $\mathrm{C} 1$ & $\mathrm{C} 2$ & $\mathrm{C} 3$ & $\mathrm{C} 4$ & $\mathrm{C} 5$ & $\mathrm{C} 6$ & $\mathrm{C} 7$ & $\mathrm{C} 8$ \\
\hline $\mathrm{C} 1$ & 1 & 0.7804 & 0.8136 & 0.7936 & 0.772 & 0.7976 & 0.8104 & 0.7972 \\
$\mathrm{C} 2$ & 0.7804 & 1 & 0.8040 & 0.8336 & 0.76 & 0.8196 & 0.7836 & 0.8 \\
$\mathrm{C} 3$ & 0.8136 & 0.804 & 1 & 0.8008 & 0.7872 & 0.798 & 0.8048 & 0.8276 \\
$\mathrm{C} 4$ & 0.7936 & 0.8336 & 0.8008 & 1 & 0.8 & 0.7812 & 0.76 & 0.76 \\
$\mathrm{C} 5$ & 0.772 & 0.76 & 0.7872 & 0.8 & 1 & 0.74 & 0.788 & 0.754 \\
C6 & 0.7976 & 0.8196 & 0.798 & 0.7812 & 0.74 & 1 & 0.7748 & 0.7904 \\
C7 & 0.8104 & 0.7836 & 0.8048 & 0.76 & 0.788 & 0.7748 & 1 & 0.8432 \\
C8 & 0.7972 & 0.8 & 0.8276 & 0.76 & 0.754 & 0.7904 & 0.8432 & 1 \\
\hline
\end{tabular}

Table 8 Matrix of weights before normalization $(t)$

\begin{tabular}{lllllllll}
\hline T & C1 & C2 & C3 & C4 & C5 & C6 & C7 & C8 \\
\hline C1 & 1 & 0.0672 & 0.2100 & 3.5630 & 0.1450 & 0.0932 & 0.2778 & 0.3713 \\
C2 & 10.5813 & 1 & 0.7428 & 1.9671 & 0.5094 & 0.5883 & 1.0617 & 1.5794 \\
C3 & 3.6981 & 0.9738 & 1 & 5.8793 & 3.5089 & 1.6842 & 4.2025 & 6.7218 \\
C4 & 0.2468 & 0.3832 & 0.1224 & 1 & 0.8481 & 0.7033 & 0.2735 & 1.8927 \\
C5 & 5.0497 & 1.3399 & 0.2015 & 0.8481 & 1 & 0.9696 & 9.2470 & 3.4748 \\
C6 & 7.9032 & 1.2561 & 0.4259 & 0.9975 & 0.6864 & 1 & 2.9671 & 2.6822 \\
C7 & 2.7792 & 0.6628 & 0.1723 & 2.4951 & 0.0765 & 0.2344 & 1 & 0.7635 \\
C8 & 2.0981 & 0.4555 & 0.1111 & 0.3606 & 0.1949 & 0.2647 & 1.0010 & 1 \\
\hline
\end{tabular}

Weights of main criteria are computed using Eq, (13). Due to field constraints, not all the calculations related to the sub-criteria could be shown using PFAHP.

Similarly, in Table 9 weights of sub evaluation criteria are shown following the PFAHP procedure for weighting eight main criteria.

Table 9 Importance weights supplier evaluation criteria

\begin{tabular}{lllll}
\hline Criteria & $\begin{array}{l}\text { Local } \\
\text { weights }\end{array}$ & $\begin{array}{l}\text { Ranking } \\
\text { Order }\end{array}$ & $\begin{array}{l}\text { Global } \\
\text { Weight }\end{array}$ & $\begin{array}{l}\text { Ranking } \\
\text { Order }\end{array}$ \\
\hline C1-Environmental & 0.0518 & & & \\
C11: Environment management systems & 0.1124 & 5 & 0.0058 & 35 \\
C12: Green design and purchasing & 0.2247 & 2 & 0.0116 & 28 \\
C13: Green manufacturing & 0.0677 & 6 & 0.0035 & 39 \\
C14: Green management & 0.1499 & 3 & 0.0078 & 32 \\
C15: Green packing and labeling & 0.1428 & 4 & 0.0074 & 33 \\
C16: Waste management and pollution prevention & 0.2576 & 1 & 0.0133 & 24 \\
C17: Environmental competencies & 0.0447 & 7 & 0.0023 & 42 \\
C2-Social & 0.1630 & & & \\
C21: Occupational Health and Safety Systems & 0.0086 & 6 & 0.0014 & 44 \\
C22: The interests and rights of employees & 0.0785 & 5 & 0.0128 & 26 \\
C23: The rights of stakeholders & 0.1471 & 3 & 0.0240 & 18 \\
C24: Information Disclosure & 0.3286 & 2 & 0.0536 & 7 \\
C25: Labor relation records & 0.3562 & 1 & 0.0581 & 6 \\
C26: training aids & 0.0810 & 4 & 0.0132 & 25 \\
C3-Quality & 0.2501 & & & \\
C31: Low defect rate & 0.0470 & 4 & 0.0118 & 27 \\
C32: Inspections methods and plans & 0.4620 & 1 & 0.1156 & 1
\end{tabular}




\begin{tabular}{|c|c|c|c|c|}
\hline C33: Adherence to quality tools & 0.3749 & 2 & 0.0938 & 2 \\
\hline C34: Quality systems & 0.1161 & 3 & 0.0290 & 13 \\
\hline C4-Service & 0.0495 & & & \\
\hline C41: Quick Responsiveness & 0.5005 & 1 & 0.0247 & 16 \\
\hline C42: Flexibility and Agility & 0.4515 & 2 & 0.0223 & 20 \\
\hline C43: After sales service & 0.0480 & 3 & 0.0024 & 41 \\
\hline C5-Risk & 0.2001 & & & \\
\hline C51: Supply Constraint & 0.0546 & 7 & 0.0109 & 29 \\
\hline C52: Buyer Supplier Constraint & 0.1313 & 4 & 0.0263 & 14 \\
\hline C53: Supplier's past performance and reputation & 0.1275 & 5 & 0.0255 & 15 \\
\hline C54: Variation in price & 0.1455 & 3 & 0.0291 & 12 \\
\hline C55: Supplier's production limitations & 0.1210 & 6 & 0.0242 & 17 \\
\hline C56: amount of past business & 0.1575 & 2 & 0.0315 & 10 \\
\hline C57: Uncompleted orders & 0.2627 & 1 & 0.0526 & 9 \\
\hline C6-Cost/Price & 0.1620 & & & \\
\hline C61: Transportation Cost & 0.1881 & 3 & 0.0305 & 11 \\
\hline C62: Purchase cost & 0.3612 & 2 & 0.0585 & 5 \\
\hline C63: Quantity discount & 0.0408 & 4 & 0.0066 & 34 \\
\hline C64: Payment terms & 0.0217 & 5 & 0.0035 & 38 \\
\hline C65: Profit on Product & 0.3882 & 1 & 0.0629 & 4 \\
\hline C7-Capability & 0.0740 & & & \\
\hline C71: Financial capability & 0.0259 & 7 & 0.0019 & 43 \\
\hline C72: Change order capability & 0.3126 & 1 & 0.0231 & 19 \\
\hline C73: Technical capability & 0.2684 & 2 & 0.0199 & 21 \\
\hline C74: Understanding of technology & 0.0491 & 5 & 0.0036 & 37 \\
\hline C75: Engineering/technical support resources & 0.1184 & 4 & 0.0088 & 30 \\
\hline C76: Technical know how & 0.0446 & 6 & 0.0033 & 40 \\
\hline C77: Distribution capability & 0.1809 & 3 & 0.0134 & 23 \\
\hline C8-Business structure & 0.0496 & & & \\
\hline C81: Knowledge of market & 0.1729 & 4 & 0.0086 & 31 \\
\hline C82: Information systems & 0.0219 & 6 & 0.0038 & 36 \\
\hline C83: Communication system & 0.0569 & 5 & 0.0012 & 45 \\
\hline C84: Desire for business & 0.2839 & 1 & 0.0162 & 22 \\
\hline C85: Management and organizations & 0.2537 & 2 & 0.0720 & 3 \\
\hline C86: Market share & 0.2106 & 3 & 0.0534 & 8 \\
\hline
\end{tabular}

Table 9 provides the importance weight and rank of each evaluation criterion determinate by 5 experts. The results show that the five most important criteria for supplier selection are: (C32) Inspections methods, (C33) adherence to quality tools, (C85), management and organizations, (C65), profit on product, (C62) purchase cost.

\subsection{Prioritization of Suppliers using FTOPSIS}

The purchasing expert in the enterprise determined their evaluations according to the existing criteria by using Table 2. The evaluation is presented in Table 10. 
M. Yücesan 11/1 (2019) 26-41

Table 10. Evaluation of experts

\begin{tabular}{|c|c|c|c|}
\hline Criteria & Supplier 1 & Supplier 2 & Supplier 3 \\
\hline C11 & $(0.2,0.3,0.4,0.5)$ & $(0.5,0.6,0.7,0.8)$ & $(0.7,0.8,0.9,1)$ \\
\hline $\mathrm{C} 12$ & $(0.1,0.2,0.3,0.4)$ & $(0.4,0.5,0.5,0.6)$ & $(0.4,0.5,0.5,0.6)$ \\
\hline $\mathrm{C} 13$ & $(0.2,0.3,0.4,0.5)$ & $(0.5,0.6,0.7,0.8)$ & $(0.7,0.8,0.9,1)$ \\
\hline C14 & $(0.1,0.2,0.3,0.4)$ & $(0.2,0.3,0.4,0.5)$ & $(0.2,0.3,0.4,0.5)$ \\
\hline C15 & $(0.2,0.3,0.4,0.5)$ & $(0.4,0.5,0.5,0.6)$ & $(0.4,0.5,0.5,0.6)$ \\
\hline $\mathrm{C} 16$ & $(0.4,0.5,0.5,0.6)$ & $(0.5,0.6,0.7,0.8)$ & $(0.7,0.8,0.9,1)$ \\
\hline $\mathrm{C} 17$ & $(0.2,0.3,0.4,0.5)$ & $(0.2,0.3,0.4,0.5)$ & $(0.2,0.3,0.4,0.5)$ \\
\hline $\mathrm{C} 21$ & $(0.4,0.5,0.5,0.6)$ & $(0.5,0.6,0.7,0.8)$ & $(0.8,0.9,1,1)$ \\
\hline $\mathrm{C} 22$ & $(0.1,0.2,0.3,0.4)$ & $(0.2,0.3,0.4,0.5)$ & $(0.4,0.5,0.5,0.6)$ \\
\hline $\mathrm{C} 23$ & $(0.8,0.9,1,1)$ & $(0.7,0.8,0.9,1)$ & $(0.5,0.6,0.7,0.8)$ \\
\hline $\mathrm{C} 24$ & $(0.2,0.3,0.4,0.5)$ & $(0.1,0.2,0.3,0.4)$ & $(0.1,0.2,0.3,0.4)$ \\
\hline $\mathrm{C} 25$ & $(0.4,0.5,0.5,0.6)$ & $(0.2,0.3,0.4,0.5)$ & $(0.2,0.3,0.4,0.5)$ \\
\hline $\mathrm{C} 26$ & $(0.4,0.5,0.5,0.6)$ & $(0.8,0.9,1,1)$ & $(0.8,0.9,1,1)$ \\
\hline $\mathrm{C} 31$ & $(0.2,0.3,0.4,0.5)$ & $(0.4,0.5,0.5,0.6)$ & $(0.5,0.6,0.7,0.8)$ \\
\hline C32 & $(0.2,0.3,0.4,0.5)$ & $(0.5,0.6,0.7,0.8)$ & $(0.8,0.9,1,1)$ \\
\hline $\mathrm{C} 33$ & $(0.4,0.5,0.5,0.6)$ & $(0.5,0.6,0.7,0.8)$ & $(0.5,0.6,0.7,0.8)$ \\
\hline C34 & $(0.4,0.5,0.5,0.6)$ & $(0.8,0.9,1,1)$ & $(0.8,0.9,1,1)$ \\
\hline C41 & $(0.5,0.6,0.7,0.8)$ & $(0.7,0.8,0.9,1)$ & $(0.7,0.8,0.9,1)$ \\
\hline C42 & $(0.4,0.5,0.5,0.6)$ & $(0.5,0.6,0.7,0.8)$ & $(0.5,0.6,0.7,0.8)$ \\
\hline $\mathrm{C} 43$ & $(0.4,0.5,0.5,0.6)$ & $(0.4,0.5,0.5,0.6)$ & $(0.5,0.6,0.7,0.8)$ \\
\hline C51 & $(0.4,0.5,0.5,0.6)$ & $(0.5,0.6,0.7,0.8)$ & $(0.5,0.6,0.7,0.8)$ \\
\hline C52 & $(0.2,0.3,0.4,0.5)$ & $(0.1,0.2,0.3,0.4)$ & $(0.4,0.5,0.5,0.6)$ \\
\hline C53 & $(0.4,0.5,0.5,0.6)$ & $(0.1,0.2,0.3,0.4)$ & $(0,0,0.1,0.2)$ \\
\hline C54 & $(0.5,0.6,0.7,0.8)$ & $(0.4,0.5,0.5,0.6)$ & $(0.2,0.3,0.4,0.5)$ \\
\hline C55 & $(0.4,0.5,0.5,0.6)$ & $(0.2,0.3,0.4,0.5)$ & $(0.4,0.5,0.5,0.6)$ \\
\hline C56 & $(0.5,0.6,0.7,0.8)$ & $(0.8,0.9,1,1)$ & $(0.8,0.9,1,1)$ \\
\hline C57 & $(0.4,0.5,0.5,0.6)$ & $(0,0,0.1,0.2)$ & $(0,0,0.1,0.2)$ \\
\hline C61 & $(0.2,0.3,0.4,0.5)$ & $(0.4,0.5,0.5,0.6)$ & $(0.4,0.5,0.5,0.6)$ \\
\hline C62 & $(0.5,0.6,0.7,0.8)$ & $(0.7,0.8,0.9,1)$ & $(0.7,0.8,0.9,1)$ \\
\hline C63 & $(0.4,0.5,0.5,0.6)$ & $(0.1,0.2,0.3,0.4)$ & $(0.5,0.6,0.7,0.8)$ \\
\hline C64 & $(0.7,0.8,0.9,1)$ & $(0.5,0.6,0.7,0.8)$ & $(0.4,0.5,0.5,0.6)$ \\
\hline C65 & $(0.4,0.5,0.5,0.6)$ & $(0.2,0.3,0.4,0.5)$ & $(0.4,0.5,0.5,0.6)$ \\
\hline C71 & $(0.4,0.5,0.5,0.6)$ & $(0.5,0.6,0.7,0.8)$ & $(0.5,0.6,0.7,0.8)$ \\
\hline C72 & $(0.5,0.6,0.7,0.8)$ & $(0.5,0.6,0.7,0.8)$ & $(0.5,0.6,0.7,0.8)$ \\
\hline C73 & $(0.2,0.3,0.4,0.5)$ & $(0.8,0.9,1,1)$ & $(0.7,0.8,0.9,1)$ \\
\hline C74 & $(0.2,0.3,0.4,0.5)$ & $(0.8,0.9,1,1)$ & $(0.7,0.8,0.9,1)$ \\
\hline C75 & $(0.2,0.3,0.4,0.5)$ & $(0.8,0.9,1,1)$ & $(0.7,0.8,0.9,1)$ \\
\hline C76 & $(0.4,0.5,0.5,0.6)$ & $(0.8,0.9,1,1)$ & $(0.8,0.9,1,1)$ \\
\hline C77 & $(0.2,0.3,0.4,0.5)$ & $(0.5,0.6,0.7,0.8)$ & $(0.5,0.6,0.7,0.8)$ \\
\hline C81 & $(0.8,0.9,1,1)$ & $(0.5,0.6,0.7,0.8)$ & $(0.7,0.8,0.9,1)$ \\
\hline C82 & $(0,0,0.1,0.2)$ & $(0.1,0.2,0.3,0.4)$ & $(0.2,0.3,0.4,0.5)$ \\
\hline $\mathrm{C} 83$ & $(0.4,0.5,0.5,0.6)$ & $(0.2,0.3,0.4,0.5)$ & $(0.4,0.5,0.5,0.6)$ \\
\hline $\mathrm{C} 84$ & $(0.8,0.9,1,1)$ & $(0.5,0.6,0.7,0.8)$ & $(0.4,0.5,0.5,0.6)$ \\
\hline $\mathrm{C} 85$ & $(0.1,0.2,0.3,0.4)$ & $(0.2,0.3,0.4,0.5)$ & $(0.2,0.3,0.4,0.5)$ \\
\hline C86 & $(0.5,0.6,0.7,0.8)$ & $(0.4,0.5,0.5,0.6)$ & $(0.2,0.3,0.4,0.5)$ \\
\hline
\end{tabular}

The fuzzy linguistic expressions are changed into fuzzy trapezoidal numbers. This is the first phase of the FTOPSIS method. The weights of criteria which are computed in PFAHP stage are then added into the 
calculation in FTOPSIS analysis. In this stage fuzzy decision matrix computed using Eq. (15). The FPIS and the FNIS values are considered as: $(1,1,1,1)$ and $(0,0,0,0)$, For the next stage, $\mathrm{S}_{\mathrm{k}}^{+}$and $\mathrm{S}_{\mathrm{k}}^{-}$are computed using Eqs, (18) and (19). The next stage is about the similarities to an ideal solution and computed with Eq, (20). The resulting closeness coefficients values of suppliers are reported in Table 11. The supplier which has the biggest $\mathrm{Ci}^{*}$ value has performed best in terms of supplier criteria. According to Table 11, Supplier 3 has shown the best performance.

Table 11 FTOPSIS $C_{i}^{*}$

\begin{tabular}{lllll}
\hline Suppliers & $S_{i^{+}}$ & $S_{i}$ & $C_{i}^{*}$ & Order \\
\hline Supplier 1 & 76.184 & 1.357 & 0.0175 & 3 \\
Supplier 2 & 76.128 & 1.419 & 0.0183 & 2 \\
Supplier 3 & 76.042 & 1.503 & 0.0194 & 1 \\
\hline
\end{tabular}

\section{Conclusion}

Effective supplier selection plays a vital role in the success of businesses, especially in today's competitive environment. Careful consideration of suppliers by decision makers is one of the most challenging stages of the decision-making process, as there are several conflicting goals to consider. The green supply chain can be defined as the coordination of activities such as material management, information sharing, capital flow and cooperation, with the aim of minimizing the environmental impact of its operations by considering the financial interests of the company.

In this study, an application of a supplier evaluation approach including an integration of PFAHP and FTOPSIS is presented. The case study is performed under a fuzzy environment to reduce uncertainty and vagueness, and linguistic variables parameterized by interval-valued Pythagorean and triangular fuzzy numbers are used. Through the case study, 8 main and 45 sub-criteria supplier selection evaluation criteria used to assess 3 suppliers by FTOPSIS.

Although the proposed model can be developed more, it will bring several contributions to green supplier evaluation and selection literature. To our knowledge, no previous work investigated this green supplier selection problem by integrating PFAHP and FTOPSIS. As the proposed approach is novel, it might be applied to other MCDM problems. However, our study has some disadvantages and possible further work is recommended. Other possible techniques for future studies include VIKOR and Preference Ranking Organizational Method for Enrichment Evaluation (PROMETHEE). In addition, different fuzzy sets can be used in the proposed approach.

\section{References}

Ageron, B,, Gunasekaran, A,, Spalanzani, A,, 2012, Sustainable supply management: an empirical study, Int, J, Prod, Econ, 140 (1).

Ahi, P., Searcy, C. (2013). A Comparative Literature Analysis of Definitions for Green and Sustainable Supply Chain Management. Journal of Cleaner Production, 52, 329-341.

Ak, M. F., \& Gul, M. (2018). AHP-TOPSIS integration extended with Pythagorean fuzzy sets for information security risk analysis. Complex \& Intelligent Systems, 1-14.

Akarte, $\mathrm{M}, \mathrm{M}$, Surendra, N,V,, Ravi, B, Rangaraj, N, (2001), Web based casting supplier evaluation using analytical hierarchy process, Journal of the Operational Research Society 52 (5), 511-522.

Atanassov, K. T. (1986). Intuitionistic fuzzy sets. Fuzzy Sets and Systems, 20, 87-96.

Azadi, M, Jafarian, M, Saen, R,F, Mirhedayatian, S,M, 2015, A new fuzzy DEA model for evaluation of efficiency and effectiveness of suppliers in sustainable supply chain management context, Comput, Oper, Res, 54, 274e285.

Bai, C, , \& Sarkis, J, (2010), Green supplier development: Analytical evaluation using rough set theory, Journal of Cleaner Production, 18 (12), 1200-1210 , 
Brandenburg, M, Govindan, $K_{\Perp}$, Sarkis, J,, Seuring, S,, 2014, Quantitative models for sustainable supply chain management: developments and directions, Eur, J, Opera, Res, 233 (2), 299e312.

Celik, E, Gul, M, Gumus, A, T, \& Guneri, A, F, (2012), A fuzzy TOPSIS approach based on trapezoidal numbers to material selection problem, Journal of Information Technology Applications \& Management, 19(3), 19-30.

Chan, F,T,S, (2003), Interactive selection model for supplier selection process: An analytical hierarchy process approach, International Journal Production Research 41 (15), 3549-3579.

Chan, F,T,S,, Chan, H,K, (2004), Development of the supplier selection model - A case study in the advanced technology industry, Proceedings of the Institution of Mechanical Engineers Part B - Journal of Engineering Manufacture 218 (12),1807-1824.

Chan, F,T,S,, Kumar, N, (2007), Global supplier development considering risk factors using fuzzy extended AHP-based approach, OMEGA - International Journal of Management Science 35 (4), 417-431.

Chan, F. T., \& Kumar, N. (2007). Global supplier development considering risk factors using fuzzy extended AHP-based approach. Omega, 35(4), 417-431.

Chen, C, (2000), Extensions of the TOPSIS for group decision-making under fuzzy environment, Fuzzy Sets and Systems, 114, 1-9.

Chen, C.-C. (2005). Incorporating green purchasing into the frame of ISO 14000. Journal of Cleaner Production, 13, 927-933.

Chou, S. Y., \& Chang, Y. H. (2008), A decision support system for supplier selection based on a strategyaligned fuzzy SMART approach. Expert System with Applications, 34, 2241-2253.

Chou, S. Y., \& Chang, Y. H. (2008), A decision support system for supplier selection based on a strategyaligned fuzzy SMART approach. Expert System with Applications, 34, 2241-2253.

Çalık, A. (2018). Bulanık Çok-Amaçlı Doğrusal Programlama ve Aralık Tip-2 Bulanık AHP Yöntemi İle Yeşil Tedarikçi Seçimi. Selçuk Üniversitesi Sosyal Bilimler Enstitüsü Dergisi, (39), 96-109.

Denizhan, B., Yalçıner, A. Y., \& BERBER, Ş. (2017). Analitik Hiyerarşi Proses ve Bulanık Analitik Hiyerarşi Proses Yöntemleri Kullanılarak Yeşil Tedarikçi Seçimi Uygulaması. Nevşehir Bilim ve Teknoloji Dergisi, 6(1), 63-78.

D,J, Bowersox, D,J, Closs,(1996), Logistical Management: The Integrated Supply Chain Process, McGrawHill, New York,

Enarsson, L. (1998). Evaluation of suppliers: How to consider the environment. International Journal of Physical Distribution and Logistics Management, 28(1), 5-7.

Gul, M. (2018). Application of Pythagorean fuzzy AHP and VIKOR methods in occupational health and safety risk assessment: The case of a gun and rifle barrel external surface oxidation and colouring unit. International journal of occupational safety and ergonomics, (just-accepted), 1-26.

Ghodsypour, S, H.,O'Brien, C, (1998), A decision support system for supplier selection using an integrated analytic hierarchy process and linear programming, International journal of production economics, 56, 199-212.

Ha, S. H., \& Krishnan, R. (2008). A hybrid approach to supplier selection for the maintenance of a competitive supply chain. Expert Systems with Applications, 34(2), 1303-1311.

Handfield, R, , Walton, S, V, , Sroufe, R, , \& Melnyk, S, A, (2002), Applying environmen- tal criteria to supplier assessment: A study in the application of the Analytical Hierarchy Process, European Journal of Operational Research, 141 (1), 70-87.

Handfield, R,, Walton, S, V,, Sroufe, R,, Melnyk, S, A, (2002), Applying environmental criteria to supplier assessment: A study in the application of the Analytical Hierarchy Process, European journal of operational research, 141(1), 70-87. 
Handfield, R., Steven, R., Srouft, R., \& Melnyk, S. A. (2002). Applying environmental criteria to supplier assessment: A study in the application of the analytical hierarchy process. European Journal of Operational Research, 141, 70-87.

Hou, J, Su, D,, 2007, EJB-MVC oriented supplier selection system for mass customization, Journal of Manufacturing Technology Management 18 (1), 54-71.

Hsu, C,W, Kuo, T,C, Chen, S,H, Hu, A,H, 2013, Using DEMATEL to develop a carbon management model of supplier selection in green supply chain management, J, Clean, Prod, 56.

Hsu, C.W., Hu, A.H., 2009. Applying hazardous substance management to supplier selection using analytic network process. J. Clean. Prod. 17, 255e264.

Hwang, C, L, \& Yoon, K, (1981), Multiple Attribute Decision Making: Methods and Applications, A State of the Art Survey, Sprinnger-Verlag, New York, NY.

Ilbahar, E., Karaşan, A., Cebi, S., \& Kahraman, C. (2018). A novel approach to risk assessment for occupational health and safety using Pythagorean fuzzy AHP \& fuzzy inference system. Safety Science, 103, 124-136.

Jain, V,, Sangaiah, A, K,, Sakhuja, S, Thoduka, N,, \& Aggarwal, R, (2018), Supplier selection using fuzzy AHP and TOPSIS: a case study in the Indian automotive industry, Neural Computing and Applications, 29(7), 555-564.

Kahraman, C, Cebeci, U,, Ulukan, Z,, 2003, Multi-criteria supplier selection using fuzzy AHP, Logistics Information Management 16 (6), 382-394.

Kannan, D., Khodaverdi, R., Olfat, L., Jafarian, A., Diabat, A., 2013. Integrated fuzzy multi criteria decision making method and multi-objective programming approach for supplier selection and order allocation in a green supply chain. J. Clean. Prod. 47, 355e367.

Kumar, A, Jain, V,, Kumar, S, 2014, A comprehensive environment friendly approach for supplier selection, Omega 42.

Kuo, R, J, , Wang, Y, C, , \& Tien, F, C, (2010), Integration of artificial neural network and MADA methods for green supplier selection, Journal of Cleaner Production, 18 (12), 1161-1170.

Lee, A, H, (2009), A fuzzy supplier selection model with the consideration of benefits, opportunities, costs and risks, Expert systems with applications, 36(2), 2879-2893.

Lee, A, H, I, , Kang, H,-Y, , Hsu, C,-F, , \& Hung, H, C, (2009), A green supplier selection model for high-tech industry, Expert Systems with Applications, 36 (4), 7917-7927.

Liu, F, H, F, Hai, H, L, (2005), The voting analytic hierarchy process method for selecting supplier, International journal of production economics, 97(3), 308-317.

Lu, L.Y.Y., Wu, C.H., Kuo, T.C., (2007), Environmental principles applicable to green supplier evaluation by using multi-objective decision analysis. Int. J. Prod. Res.

Mete, S. (2018). Assessing occupational risks in pipeline construction using FMEA-based AHP-MOORA integrated approach under Pythagorean fuzzy environment. Human and Ecological Risk Assessment: An International Journal, 1-16.

Madan, J,, Mani, M, Lee, J, H, \& Lyons, K, W, (2015), Energy performance evaluation and improvement of unit-manufacturing processes: injection molding case study, Journal of Cleaner Production, 105, 157170 .

Marcus, A., \& Fremeth, A. (2009). Green management matters regardless. The Academy of Management Perspectives, 23(3), 17-26. Management Science 35 (4), 417-431.

Moheb-Alizadeh, H, Handfield, R, (2017), An integrated chance-constrained stochastic model for efficient and sustainable supplier selection and order allocation, International Journal of Production Research, $1-27$. 


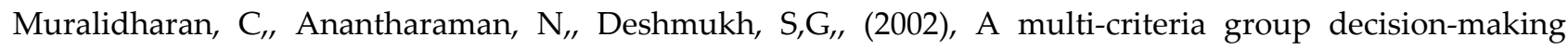
model for supplier rating, Journal of Supply Chain Management 38 (4), 22-33.

Noci, G. (1997). Designing green vendor rating systems for the assessment of a supplier's environmental performance. European Journal of Purchasing and Supply Management, 2, 103-114.

Oz, N. E., Mete, S., Serin, F., \& Gul, M. (2018). Risk assessment for clearing and grading process of a natural gas pipeline project: An extended TOPSIS model with Pythagorean fuzzy sets for prioritizing hazards. Human and Ecological Risk Assessment: An International Journal, 1-18.

Perçin, S., \& Ayan, T. Y. (2015). AHS VE BULANIK PROMETHEE YAKLAŞIMLARIYLA ESNEK ÜRETIM SİSTEMLERİ SEÇİMI. MU Iktisadi ve Idari Bilimler Dergisi, 29(2), 555-575.

Seuring, S. (2013). A review of modeling approaches for sustainable supply chain management. Decision Support System 54, 1513-1520.

Seuring, S., Müller, M, (2008), From a literature review to a conceptual framework for sustainable supply chain management, Journal of cleaner production, 16(15), 1699-1710.

Tayalı, H. A. (2017). Tedarikçi Seçiminde WASPAS Yöntemi. Akademik Sosyal Araştırmalar Dergisi, 5(47), 368-380.

Tsai, W-H, , \& Hung, S,-J, (2009), A fuzzy goal programming approach for green supply chain optimization under activity-based costing and performance evaluation with a value-chain structure, International Journal of Production Research, 47 (18), 4991-5017.

Tseng, M.L., (2011), Green supply chain management with linguistic preferences and incomplete information. Appl. Soft Comput. 11 (8).

Tzeng, G, H, \& Huang, J, J, (2011), Multiple attribute decision making: methods and applications, CRC Press.

Tzeng, G. H., \& Huang, J. J. (2011). Multiple attribute decision making: methods and applications. Chapman and Hall/CRC.

Walton, S. V., Handfield, R. B., \& Melnyk, S. A. (1998). The green supply chain: Integrating suppliers into environmental management processes. International Journal of Purchasing and Materials Management, 34(2), 2-11.

Yager, R. R. (2014). Pythagorean membership grades in multicriteria decision making. IEEE Transactions on Fuzzy Systems, 22(4), 958-965.

Yucesan, M.; Mete, S.; Serin, F.; Celik, E.; Gul, M. (2018), An Integrated Best-Worst and Interval Type-2 Fuzzy TOPSIS Methodology for Green Supplier Selection. Preprints, 2018120368 (doi: 10.20944/preprints201812.0368.v1)

Yucesan, M., \& Kahraman, G. (2019). Risk evaluation and prevention in hydropower plant operations: A model based on Pythagorean fuzzy AHP. Energy Policy, 126, 343-351.

Zhang, X., \& Xu, Z. (2014). Extension of TOPSIS to multiple criteria decision making with Pythagorean fuzzy sets. International Journal of Intelligent Systems, 29(12), 1061-1078.

Zhu, Q, Dou, Y, , \& Sarkis, J, (2010), A portfolio-based analysis for green supplier management using the analytical network process, Supply Chain Management: An International Journal, 15 (4), 306-319.

Zhu, Q., \& Geng, Y. (2001). Integrating environmental issues into supplier selection and management. Greener Management International, 35, 27-40.

Zouggari, A., Benyoucef, L., (2012). Simulation based fuzzy TOPSIS approach for group multi-criteria supplier selection problem. Eng. Appl. Artif. Intell. 25 (3). 